\title{
VOZES INTERCALADAS ENTRE A LITERATURA E A HISTÓRIA ANGOLANAS: TESSITURAS EM MAYOMBE E NOITES DE VIGÍLIA
}

\author{
Derneval Andrade FERREIRA ${ }^{1}$ \\ Instituto Federal de Educação, Ciência e Tecnologia - IF-BAIANO -BA. \\ (Derneval.f@hotmail.com) \\ Adelino Pereira dos SANTOS ${ }^{2}$ \\ Universidade do Estado da Bahia - UNEB - BA. \\ (adesantos@uneb.br)
}

\begin{abstract}
Resumo: Neste trabalho, discutimos as relações entre a Literatura e a História a partir de considerações sobre os romances Mayombe e Noites de Vigília, dos escritores angolanos Pepetela e Boaventura Cardoso, respectivamente. Amparados em pressupostos teóricos da Crítica Literária e da Nova História Cultural, assumimos o ponto de vista de que as relações entre a Literatura e a História se dão muito além de meras fontes documentais, mas de tessituras em que as vivências, sentimentos e experiências dos escritores e historiadores deixam registradas nas páginas dos romances e nas narrativas historiográficas. Por meio da análise que aqui apresentamos pudemos evidenciar que os autores dessas narrativas conseguem expressar o imaginário histórico-cultural angolano, problematizar conflitos e tensões e, ao mesmo tempo, construir, por meio de uma escrita convocatória, momentos de inquietações, de releituras, sobre fatos da história angolana. Concluímos que a arte literária não é apenas um elemento que enfatiza ilusões, devaneios, mas, sobretudo, transforma-se em um recurso capaz de refletir as ações do homem e suas vivências na sociedade, assim como consegue, ainda, reconfigurar ideias e anseios de uma determinada época.
\end{abstract}

Palavras-chave: Literatura; História; Pepetela; Boaventura Cardoso; Angola.

\section{VOICES INTERCALATED BETWEEN LITERATURE AND ANGOLAN HISTORY: TESSITURES IN MAYOMBE AND NOITES DE VIGÍLIA}

\begin{abstract}
In this work, we discuss the relations between Literature and History based on considerations about the novels Mayombe and Noites de Vigília, by Angolan writers Pepetela and Boaventura Cardoso, respectively. Based on the theoretical assumptions of Literary Criticism and New Cultural History, we take the view that the relations between Literature and History are much more than mere documentary sources, but of texture in which life, feelings and experiences of writers and historians are recorded in the pages of novels and historiographical narratives. Through the analysis presented here, we could show that the authors of these narratives are able to express the Angolan historical-cultural imagery, to problematize conflicts and tensions and, at the same time, to construct, by means of an inviting writing, moments of restlessness, of re-reading, about facts of Angolan history. We concluded that literary art is not only an element that emphasizes illusions, but also, above all,
\end{abstract}

\footnotetext{
${ }^{1}$ Doutor em Estudos Étnicos e Africanos pela Universidade Federal da Bahia. Professor de Língua Portuguesa do Instituto Federal de Educação, Ciência e Tecnologia da Bahia - IF-BAIANO.

2 Doutor em Letras pela Universidade Federal da Bahia. Professor Titular do Departamento de Ciências Humanas do Campus V da Universidade do Estado da Bahia.
} 


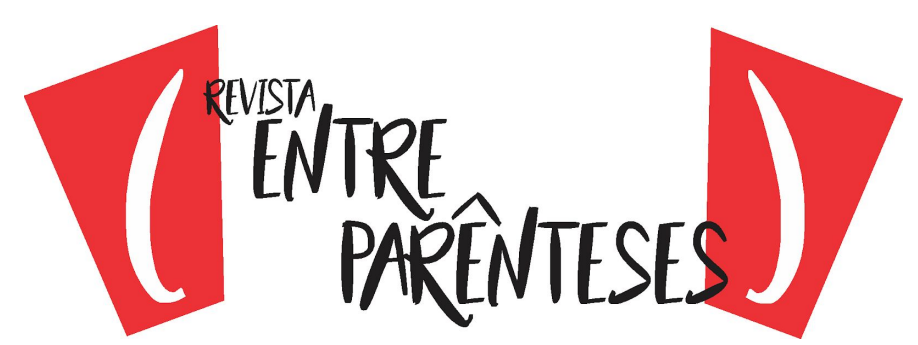

becomes a resource capable of reflecting the actions of men and their experiences in society, as well as being able to reconfigure ideas and desires of a given time.

Keywords: Literature; History; Pepetela; Boaventura Cardoso; Angola.

\section{VOCES INTERCALADAS ENTRE LA LITERATURA Y LA HISTORIA ANGOLANA: TESITURAS EN MAYOMBE Y NOITES DE VIGÍLIA}

Resumen: En este trabajo, discutimos las relaciones entre la Literatura y la Historia partiendo de consideraciones sobre los romances Mayombe y Noites de Vigilia, de los escritores angoleños Pepetela y Boaventura Cardoso, respectivamente. Apoyados en supuestos teóricos de la Crítica Literaria y de la Nueva Historia Cultural, asumimos el punto de vista de que las relaciones entre la Literatura y la Historia se dan mucho más allá de meras fuentes documentales, se dan también en las vivencias, sentimientos y experiencias que los escritores y los historiadores dejan registrados en las páginas de los romances y en las narrativas historiográficas. Por medio del análisis que aquí presentamos pudimos evidenciar que los autores de esas narrativas logran expresar el imaginario histórico-cultural angoleño, problematizar conflictos y tensiones y, al mismo tiempo, construir, por medio de una escritura convocatoria, momentos de inquietudes, de relecturas, sobre hechos de la historia angoleña. Concluimos que el arte literario no es sólo un elemento que enfatiza ilusiones, devaneos, pero, sobre todo, se transforma en un recurso capaz de reflejar las acciones del hombre y sus vivencias en la sociedad, así como consigue, aún, reconfigurar ideas y anhelos de una determinada época.

Palabras clave: Literatura; História; Pepetela; Boaventura Cardoso; Angola.

\section{O DISCURSO LITERÁRIO E A HISTÓRIA ANGOLANA}

O discurso literário não deve ser oposto dicotomicamente ao discurso histórico, como duas realidades distintas e distantes, mas, sobretudo, como formas plurais que dialogam permanentemente. Haverá sempre um traço de literatura riscando a história e vice-versa, isto porque no plano material que contorna as palavras, os signos, os traços, há, inevitavelmente, uma rede de intenções dos articuladores dos discursos. Além disso, as unidades textuais permitem que se mergulhe no mundo da descontinuidade para, através dela, criar novos significados e redefinir olhares.

A possibilidade de historiadores, por exemplo, utilizarem a obra literária como fonte historiográfica reforça o princípio norteador da História Cultural no que tange ao dialogismo proposto por ela. Os interesses na catalogação dos gêneros 


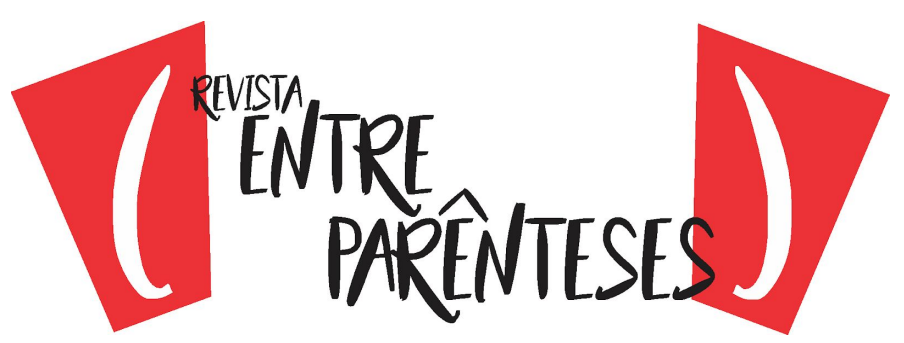

passam por várias maneiras de se ler um texto, permitindo, assim, tanto ao leitor quanto ao historiador, a distinção entre "ficção" e "verdade", elementos que Roger Chartier (2001) considera importantes para restabelecer uma leitura complementar envolvendo história e literatura, permitindo, desse modo, realizar uma possível relação entre os campos da arte literária e a história. Sobre esse aspecto, Chartier (2001) pontua que

Este elementos parecem indicar vários dos termos dignos de atenção para restabelecer uma leitura histórica das obras literárias que não destrua sua condição literária. Porque há historiadores que se interessam em fazer leituras das obras literárias, mas frequentemente sem sucesso, pois as liam como se fossem um documento singular que ilustrava os resultados ou que corroborava o que as fontes e as técnicas clássicas da história tinham mostrado. Assim, é uma leitura redutiva, puramente documental e que destrói o próprio interesse de se confrontar com a literatura. (CHARTIER, 2001, p. 20).

Outro aspecto entre história e literatura refere-se à utilização do texto literário como fonte para se discutir aspectos históricos e vice-versa. Nessa perspectiva, "a história foi recurso para, através dos mitos de que qualquer história nacional vive, se constituir como veículo de afirmação cultural e reivindicação política" (MATA, 2009, p. 196) e, dessa forma, acaba auxiliando a pesquisa e a análise históricas. Nesse contexto, a literatura não se constituiria em mero reflexo da sociedade, mas, sobretudo, como um elemento mediador capaz de compreendê-la.

Quando se pretende realizar, por exemplo, um estudo literário de obras referentes às literaturas africanas de língua portuguesa, não está em discussão tão somente uma série de elementos que representam as sociedades africanas, mas também um conjunto de imagens mediadoras que ajudam a compreendê-las. As narrativas Mayombe, de Pepetela, e Noites de Vigília, de Boaventura Cardoso, nesse contexto, não são apenas recursos que podem refletir aspectos sociais, mas um caminho, um percurso, um instrumento que exprimem elementos que ajudam a 


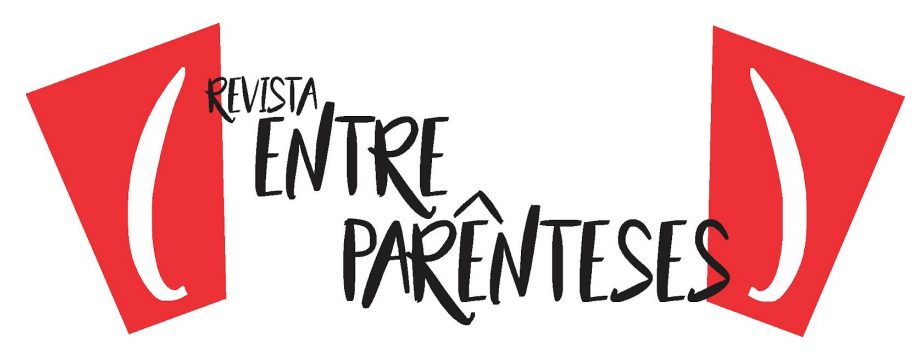

entender melhor a sociedade angolana. Por isso, "abordar qualquer obra ou aspecto de qualquer obra é revisitar fragmentos da história da sociedade angolana" (ROSÁRIO, 2009, p. 226), mediando, inclusive, passado e presente.

Em Mayombe a abordagem sobre a guerra aproxima-se muito da realidade posta da sociedade angolana em momentos antecedentes à independência política do país. Os constantes diálogos entre o Comandante Sem Medo, o Comissário e o Chefe de Operações a respeito da decisão de Teoria continuar na expedição logo após a um acidente demonstram não apenas uma proteção ao companheiro, mas também, como diversas vozes vão surgindo no interior da obra, evidenciando preocupações sobre a formação da própria ação da guerra frente a um futuro ataque do inimigo. O diálogo entre o Comandante e o Comissário demonstra isso:

- É evidente que a razão objectiva está do lado do Comissário Disse o Comandante. - No entanto, eu compreendo o camarada Teoria... Por mim, se ele acha que pode continuar, não me oponho. Mas objectivamente o Comissário tem razão...

- E subjectivamente? - perguntou o Comissário.

- Subjectivamente... sabes? Há vezes em que um homem precisa de sofrer, precisa de saber que está a sofrer e precisa de ultrapassar o sofrimento. Para quê, porquê? Às vezes, por nada. Outras vezes, por muita coisa que não sabe, não pode ou não quer explicar. Teoria sabe e pode explicar. Mas não quer, e acho que nisso tem razão.

- O problema é que se trata duma operação de guerra e não dum passeio. Num passeio, um tipo pode agir contra toda a razão, só porque the apetece ir pela esquerda em vez de ir pela direita. $\mathrm{Na}$ guerra não tem esse direito, arrisca a vida dos outros... (PEPETELA, 1990, p. 15-16).

Abordando elementos relativos à guerrilha, o texto ficcional aproxima-se da realidade em alguns aspectos. Alertar em pôr ou não em risco a vida do companheiro, definições de estratégias, diálogos constantes sobre a situação vivenciada pelos personagens problematizam questões próximas da vida real. É dessa forma que o autor apropria-se de contextos reais e os dota de imaginação, 


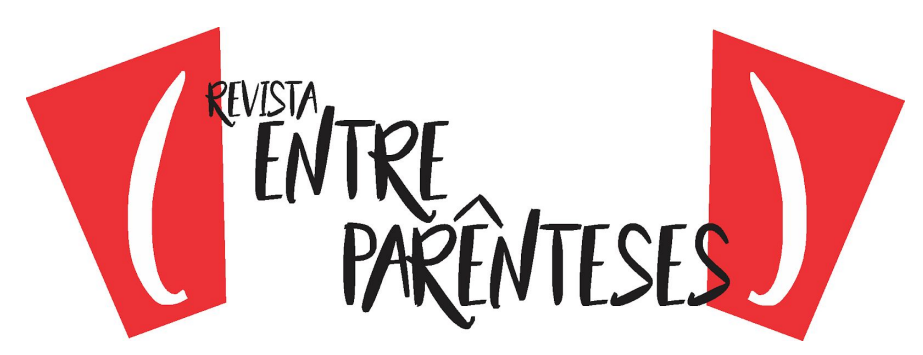

trazendo-os para o plano da ficção. Em contato com o texto, o leitor, por sua vez, penetra na rede de imaginação e cria outros sentidos e cenas imaginárias, até porque, segundo Iser (2002, p. 384), "o real e o imaginário não podem ser fundados um num outro, no entanto, um serve de contexto para o outro".

Não se pode perder de vista que "os textos literários são de natureza ficcional” (ISER, 2002, p. 384), entretanto, os enfoques políticos e sociais dados por Pepetela devem ser sempre instrumentos de reflexão pelo fato de esse autor aproximar seus escritos da realidade de seu país, principalmente se se considerar que "o imaginário penetra diretamente em nossa experiência e no ato de fingir, o imaginário ganha uma determinação que não lhe é própria e adquire um predicado de realidade" (ISER, 2002, p. 386). Essa concepção remete ao que o escritor alemão chama de transgressão de limites ocorrido tanto no processo de elaboração do texto ficcional quanto no ato de leitura. Dessa forma, as apropriações que o leitor faz do texto permitem a formulação e a reformulação de mundos experimentados pelo receptor. Quando se tenta compreender o texto ficcional e suas relações com a história, é preciso distanciar-se de qualquer relação opositiva que os envolva e admitir que sua compreensão perpassa pelo viés da inter-relação entre o real, o fictício e o imaginário, assim como defende Iser ( 2002):

desaparece assim a oposição entre ficção e realidade, pois, como "saber tácito", ela sempre implica um sistema referencial que o ato de fingir, enquanto transgressão de limites, não mais pode levar em conta. Pois se trata agora de buscar relações, em vez de determinar posições. Isso ao mesmo tempo significa afastar-se do projeto constante de um lugar transcendental, sempre tido como necessário quando se tratava de comprovar, através da predicação correspondente, serem ficção e realidade pólos opostos. (ISER, 2002, p. 387)

Ainda sobre a decisão do personagem Teoria prosseguir ou não na expedição, o Comandante resolve deixar nas mãos do próprio Teoria a disposição de partir com os guerrilheiros ou ficar, como lemos no diálogo abaixo: 
[...] O enfermeiro diz que a coisa não é grave, só dolorosa. Passará depressa. Porque não dar-lhe uma possibilidade?

- Mas possibilidade de quê? Isso é que não compreendo!

- Pois não! Possibilidade de ... sei lá! Ele é que sabe: Mas com certeza não quererá dizer, e concordo com ele. O camarada Teoria tinha duas hipóteses: ir ou não ir. Escolheu a primeira. Talvez mal, talvez sem muito reflectir, mas escolheu. [...] Se quer partir a cabeça, se escolheu partir a cabeça, devemos dar-lhe a liberdade de partir a cabeça.

- Isso é liberalismo!

-Lá vens tu com os palavrões! É possível que seja liberalismo. Mas eu não sou Comissário Político. É a ti que compete politizar-nos e defender a posição política justa. Posso ser liberalista de vez em quando, pois tenho-te sempre como anjo-da-guarda para me guiar. (PEPETELA, 1990, p.16).

Observa-se que a fala do Comissário é marcada pelo termo "liberalismo", léxico que no sentido usado exprime a ideia de voluntarismo associado a uma liberdade de escolha. Imagina-se que os personagens criados por Pepetela em Mayombe tornam-se livres, mesmo vivenciando as durezas de um período marcado pelas leis colonialistas. Essa liberdade de escolha concedida a Teoria parece uma das formas de revelar os anseios de um povo por meio de uma personagem que não apenas exprime sua vontade de prosseguir na guerrilha, mas, sobretudo, demonstra força, coragem, espírito de luta e companheirismo. A narrativa, nesse momento, constitui-se em um instrumento capaz de lutar contra as forças coloniais e, por meio do diálogo entre os personagens, percebe-se ainda que o discurso literário serve como recurso de reflexões históricas, revelando muitas vezes imagens que foram apagadas ou rechaçadas historicamente. A partir de interpretações desse gênero, percebe-se o quanto a relação entre história e literatura se faz presente cada vez mais nos estudos contemporâneos, proporcionados, sobretudo, pela nova ordem da história cultural. Dessa forma, os discursos literários fazem parte do cotidiano e, através deles, as sociedades podem ser abordadas, pois os romances narram 


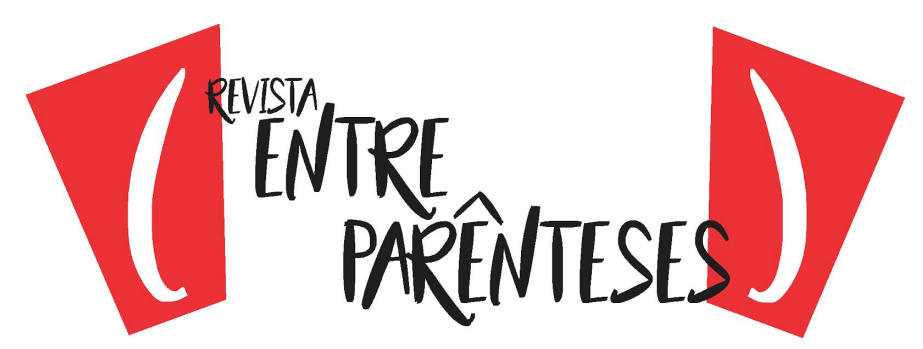

histórias, expressam imaginários, descortinam ideologias, revisam o passado e conseguem ainda projetar imagens no outro.

Assim é que, abordando temáticas relacionadas à sociedade angolana que incidem aspectos relativos à guerrilha, lutas que marcaram o processo de independência de Angola, as narrativas em análise abrem espaços para que se discutam questões tanto no âmbito da historiografia quanto da estética literária. Evidentemente que a trama narrativa é elaborada por aspectos imaginários, levando em consideração sentimentos, dor, angústia, medo que muitas vezes chegam a ultrapassar os limites da própria fantasia; no entanto, vale lembrar também que essa imaginação não provém de aspectos niilistas, pelo contrário, ela está atrelada a fatores de experiências e vivências de quem a elabora. É a partir dessa perspectiva que se percebe a possibilidade de um intercâmbio entre os estudos literários e os históricos, a fim de se investir na diluição de fronteiras que por muitos anos se mantiveram distantes.

Outro aspecto que estreita a relação entre ficção e realidade é o momento em que o narrador descreve as escolhas que os militantes guerrilheiros fizeram, os caminhos percorridos e as opções de vida que tomaram para entrar na guerra e defender seu povo, na conquista da formação da nação. O narrador faz uma série de interrogações:

[...] Porquê Sem Medo abandonou o curso de Economia, em 1964, para entrar na guerra? Porquê o Comissário abandonara Caxito, o pai velho e pobre camponês arruinado pelo roubo das terras de café, e viera? Talvez o Comissário tivesse uma razão mais evidente que os outros, sim. Porquê o Chefe de Operações abandonara os Dembos? Porquê Milagre abandonara a família? Porquê Muatiânvua, o desenraizado, o marinheiro, abandonara os barcos para agora marchar a pé, numa vida de aventura tão diferente da sua? E porquê ele, Teoria, abandonara a mulher e a posição que podia facilmente adquirir? Consciência política, consciência das necessidades do povo! Palavras fáceis, palavras que, no fundo, nada diziam. Como age em cada um deles essa dita consciência? (PEPETELA, 1990, p.18). 


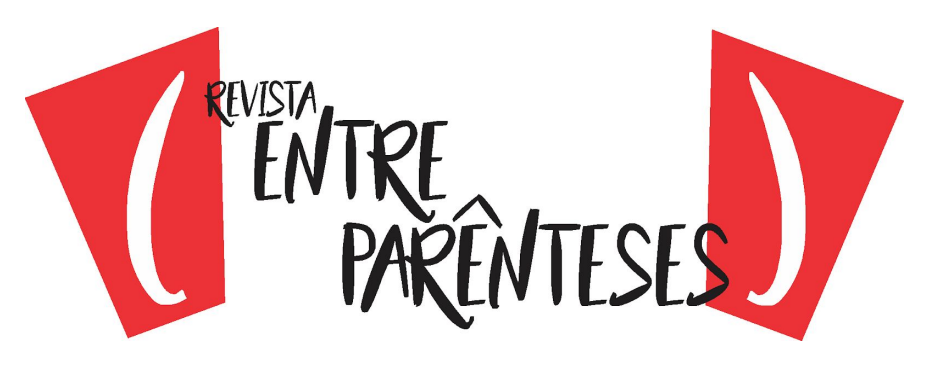

Como bem afirma Ojo-Ade (s/d, p. 48) "o pesquisador, o intelectual tem que ser a voz autêntica do povo". Nesse momento, o romancista, além de adquirir um papel de pesquisador e intelectual, reconstrói momentos e partes importantes da história, dos homens e da guerra, isso porque as situações descritas e vivenciadas pelos personagens são próximas às expectativas vivenciadas pelos homens convocados para a guerra. Se a guerra é brutal por natureza, mais violentas são as escolhas que muitas vezes são, compulsoriamente, realizadas, criando novos cenários, reconfigurando papéis e redefinindo rotinas em prol de conquistas, agremiações, prestígios e liberdades caras, mas necessárias para se vislumbrar novos horizontes. Uma primeira versão deste trabalho foi apresentada como seção de capítulo da tese de doutorado de um dos autores deste trabalho, defendida em 2016.

\section{PEPETELA EM MAYOMBE : TESSITURAS}

Pepetela e Boaventura Cardoso apropriam-se de elementos culturais, de mitos e crenças e os transformam em cenas capazes de dialogar com a história política e social de seu país, abrindo espaços para uma abordagem que se aproxima da nova história cultural, pois os autores conseguem criar e recriar partes de contextos políticos e culturas de Angola por intermédio da captação das múltiplas representações discursivas presentes nos romances.

Diferentemente da história, que se inscreve no método e apresenta rigor científico, a literatura pauta-se no imaginário. No entanto, é importante lembrar que a literatura revela a sociedade tão bem quanto a própria história o faz, por que a literatura não nasce do nada, ela lança mão de valores históricos e culturais existentes, fornecendo-nos múltiplas possibilidades de leituras, interpretações e significações. Dessa forma, há uma correlação muito grande entre o campo histórico e o literário através da renovação de diálogos em torno da verdade e da ficção, do 


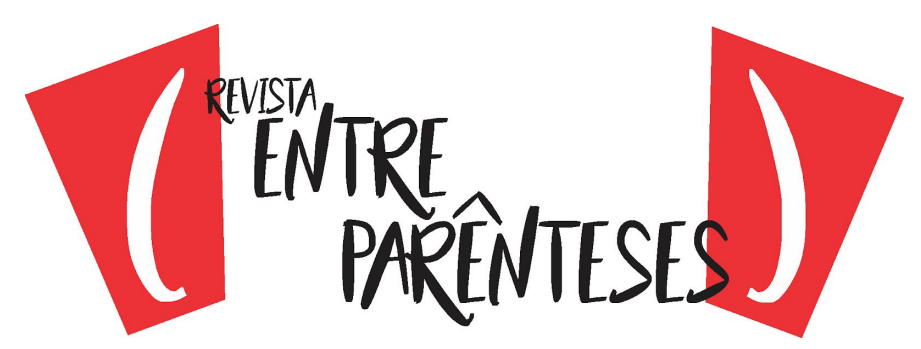

real e do imaginário, capaz de construir discursos que tentam dar sentido ao mundo. Sobre a relação literatura e história, Mata (2010) afirma ainda que

não apenas o historiador, mas também o ficcionista (romancista, novelista ou contista), têm a tarefa de olhar o passado como um "tempo informe" que carece de ordenação e sentido - afinal, a História hoje, na concepção de Philippe Ariès, abre-se ao problema contemporâneo e se torna expressão. (MATA, 2010, p. 146).

Reconhecendo que "Mayombe é, mais uma vez, um "registro" do que foi a guerrilha na frente do Cabinda" (MATA, 2009, p. 195), percebe-se que Pepetela textualizou os confrontos e as ações de guerrilha de modo que se aproximassem ao máximo da realidade vivenciada. A fala do Comandante, abaixo, expressa estratégias definidas no interior da guerra para fins de ataques e, ao mesmo tempo, de proteção; e, por isso, a cena possibilita uma vivência do passado, da própria guerra, além de uma projeção simbólica de homens reais, envolvidos na guerrilha, com sujeitos imaginários que retratam muito bem o cenário do conflito:

- Temos um guia às dimensões da Região! Bem. Verdade e Muatiânvua vão pela esquerda, com o Comissário. Milagre, Pangu Akitina e o Das Operações vão pela direita. Nós ficamos aqui. Vejam o que há e voltem. Cuidado, nada de tiros! É preciso saber se há soldados.

$$
[\ldots]
$$

Ruídos de ramos partidos e, em seguida, um fragor que cobriu todo o tumulto do Mayombe e ficou a ressoar nas copas das árvores, até se ir diluindo, aos poucos, pelos vales do Lombe.

Os pensamos do Comandante não iam mais longe. Eram fotografias que tirava aos elementos do grupo e que classificava num ficheiro mental, sem mais se preocupar. Quando necessário,servia-se dessas informações para ter uma imagem fiel de cada guerrilheiro e saber que tarefa dar a cada um. (PEPETELA, 1990, p. 27-28). 


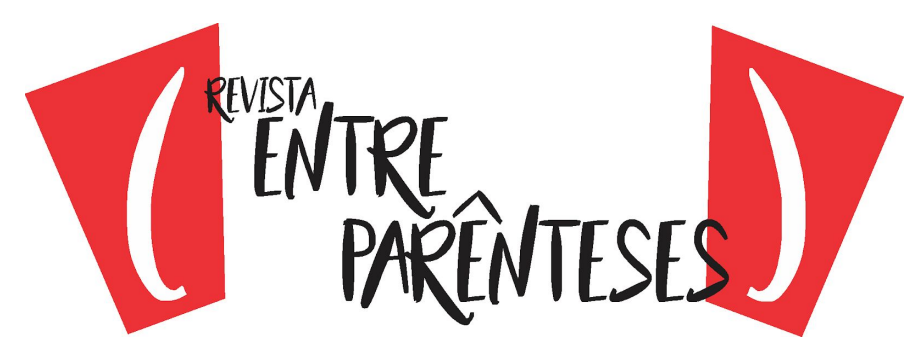

diálogo entre os personagens O Comissário e o Das Operações sobre o apoio popular às ações de guerrilhas remete a uma possível discussão entre o texto literário e o histórico:

- Esse apoio só se consegue com as armas - disse o Das Operações.

- Não só. Com as duas coisas. Com as armas e com a politização. Temos de mostrar primeiro que não somos bandidos, que não matamos o povo. O povo daqui não nos conhece, só ouve a propaganda inimiga, tem medo de nós. Se apanharmos os trabalhadores, os tratarmos bem, discutirmos com eles e, mais tarde, dermos uma boa porrada no tuga, então sim, o povo começa a acreditar e a aceitar. Mas é um trabalho longo. De qualquer modo, esta ação pode não impedir que se faça também uma emboscada.

- Questão de tempo e de comida - disse Sem Medo.

- Os camaradas aceitarão passar um pouco de fome, se lhes explicarmos o interesse da coisa. (PEPETELA, 1990, p. 30).

Nesse momento, a narrativa de Pepetela adquire uma funcionalidade expressiva, evidenciando elementos importantes numa ação militar. Se os guerrilheiros do Mayombe desejavam combater os inimigos não apenas com armas, mas, sobretudo, pelo viés da politização, numa tentativa de demonstrar a importância das ações, percebe-se que a estética literária adquire uma feição combativa e, ao mesmo tempo, pragmática.

Discutir com os trabalhadores, tratá-los bem e depois realizar uma emboscada aos colonialistas significa criar elementos necessários para enfrentar as forças colonialistas, e conseguir o apoio popular constituiria o mote principal para alcançar a nacionalidade. Dessa forma, os relatos em Mayombe adquirem uma conotação social, apresentam vieses políticos, permitindo que a narrativa apresente um caráter funcional, assim como Mata (2009) lembra:

é disso também que quero falar: de uma escrita que se questiona, que pensa a sua funcionalidade e a sua eficácia para além da ficcionalidade, de uma escrita que finta o "doce" e explode no "útil", uma escrita que, como polariza Stephen Greenblatt, confronta 


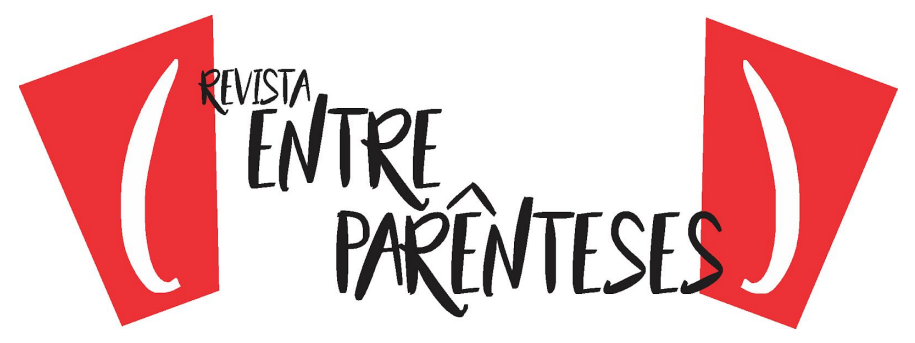

dolorosamente "prazer" e "interesse". Prazer estético e interesse pedagógico e ideológico. (MATA, 2009, p. 194).

Outras observações instigantes sobre a sociedade angolana no período colonial também são evidenciadas no fragmento abaixo:

os guerrilheiros dispersaram para avançar. A serra mecânica abelha furando um morro de salalé - continuava a sua tarefa. Havia o mecânico, que acionava a serra, e o ajudante com a lata de gasolina e de óleo; mais atrás, quatro operários com machados. Todos tão embebidos na tarefa que não repararam nas sobras furtivas. Nem protestaram, quando viram os canos das pépéchás viradas para eles. Os olhos abriram-se, o imenso branco dos olhos comendo a cara toda, a boca aberta num grito que não ousou sair e ficou vibrando interiormente. O Comissário e Ekuikui avançaram para a serra. Ekuikui encostou o cano da arma às castos do mecânico:

- Não mexe!

O mecânico olhou por cima do ombro e compreendeu rapidamente a situação. Fez parar a serra. O silêncio que se seguiu furou os ouvidos dos guerrilheiros, subiu às copas das árvores e ficou pairando, misturando à neblina que encobria o Mayombe. (PEPETELA, 1990, p. 31).

Aqui, a construção discursiva realizada pelo autor é expressiva, transformando-se em estética que qualifica a sociedade da época. Personagens, objetos, a própria natureza e homens transformam-se em símbolos carregados de significados que, metaforicamente, conseguem exibir a face trágica das relações colonialistas em momentos antecedentes à libertação política do país. A "serra mecânica", na condição de objeto, e o "mecânico" na figura do homem exploram a natureza retirando-Ihe riquezas para acúmulo de bens e manutenção do poder; uma espécie de exploração similar desempenhada pelos colonizadores portugueses em grande parte do território angolano. E, se as metáforas ajudam a entender e a refletir sobre a realidade posta, compreende ainda que a expressão "fazer parar a serra" não se restringe apenas ao plano material de impedir a exploração de recursos naturais, como as árvores, as matas, mas também representa uma forma de repúdio 


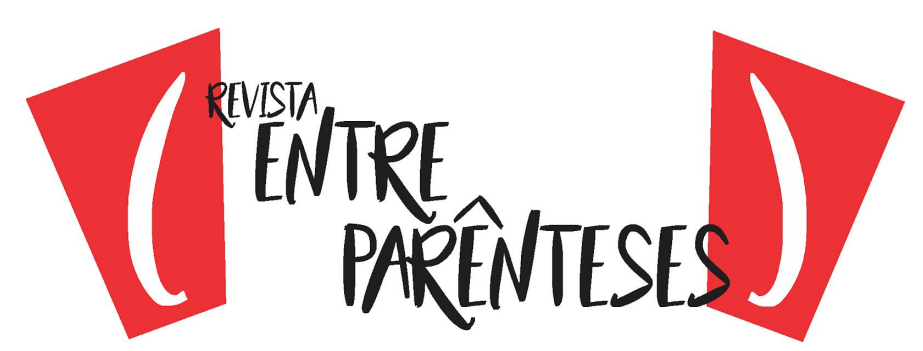

às forças colonialistas, uma espécie de combate, de resistência e de luta. Então, "fazer parar a serra" pode implicar em "fazer parar a exploração, o domínio e a colonização". É nesse aspecto que a literatura pepeteliana visa à encenação de um processo revolucionário e os relatos beiram a realidade, visto que "a relação entre historia/ficção, sendo uma constante nas literaturas que emergem de situações conflituais em processos de autonomização (política, cultural, social), é na literatura angolana, singular" (MATA, 2009, p.195).

Diante das diversidades vividas pelos sujeitos na guerra, esses mesmos "homens" expressam sentimentos como medo, angústia e saudade, inerentes aos próprios sujeitos e guerrilheiros humanizados que também lutaram contra 0 colonialismo, contra os portugueses pela constituição da nação angolana. Isso leva a crer que as descrições feitas por Pepetela, muitas vezes com um grau épico, outras vezes romanesco, apresentam características do mundo real, transformando a narrativa numa proposta também historicizante. A esse respeito, Sidney Chalhoub e Leonardo Affonso de M. Pereira (1998) afirmam que

a proposta é historicizar a obra literária - seja ela conto, crônica, poesia ou romance -, inseri-la no movimento da sociedade, investigar as suas redes de interlocução social, destrinchar não a sua suposta autonomia em relação à sociedade, mas sim a forma como constrói ou representa a sua relação com a realidade social algo que faz mesmo ao negar fazê-lo.(CHALHOUBE; PEREIRA, 1998, p. 7).

A evidência de narrativas históricas na obra de Pepetela é assinalada pelo cruzamento entre a história de Angola, a cultura e fatores sociais bem realizados pelo autor marcados por aspectos individuais e coletivos. $E$ isso ocorre muito bem ao longo da narrativa analisada: "Nós sempre dizemos para os angolanos desertarem do exército. As balas não escolhem - disse o Comissário" (PEPETELA,1990, p. 67). Ou ainda: "Ingratidão deve ser fuzilado, por roubar bens do povo” (PEPETELA, 1990, p. 69); “- Tu és um sentimental, Sem Medo! disse o 


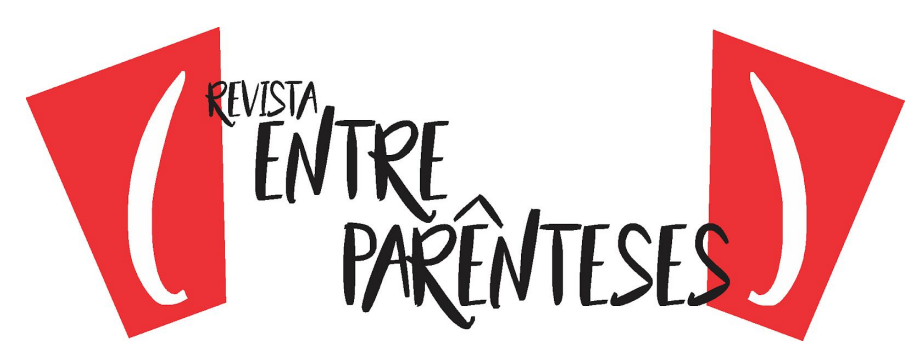

Comissário, alterado" (PEPETELA,1990, p. 71). Também aqui: "é esta injustiça a que assistimos, sem poder fazer nada. Quando mudará isto? Oh, Nzamibi, quando mudará isto?" (PEPETELA, 1990, p. 73). Por mais presentes que se façam as marcas no texto literário, em suas entrelinhas, existem sinais de um discurso que redimensiona as relações entre ficção e realidade, entre imaginação e fato ocorrido.

A narrativa Mayombe abre uma perspectiva de discussão sobre a abordagem de diversos temas referentes à sociedade angolana. Esse romance apresenta elementos que possibilitam múltiplos olhares sobre a história de um país que vivenciou situações árduas em busca da nacionalidade, tornando-se assim um componente passível de diversas construções de sentido, principalmente pelo fato do discurso literário permitir esse efeito. Sobre o autor angolano, Rosário (2009) afirma que,

\begin{abstract}
investido de todo o poder mágico e profético que só aos eleitos, aos génios e aos poetas é concedido, Pepetela não só sintetiza como também antecipa fenómenos sociais, políticos, econômicos, culturais, mitológicos e até simbólicos que as gentes que habita o território de Angola viveram e vêm vivendo antes e depois da chegada dos primeiros navegantes europeus. (ROSÁRIO, 2009, p. 115).
\end{abstract}

Em diversas partes da narrativa, Pepetela desempenha um papel de visionário da história de Angola e, ao problematizar os papéis dos guerrilheiros em momentos anteriores à independência, ele descreve situações que são registradas pela versão oficial da história de seu país. Os personagens Sem Medo e Lutamos refletem pontos de encontro entre imaginação e realidade em relação ao quadro político instaurado em Angola:

- Tens de te convencer que precisas de estudar. Como serás útil depois da luta? Mal sabes ler... onde vais trabalhar?

- Fico no exército - disse Lutamos.

- E julgas que para ficar no exército não tens de estudar? Como vais aprender artilharia ou táctica militar ou blindados? Precisas de matemática, de Física...

- Ora! Eu não quero ser oficial. 


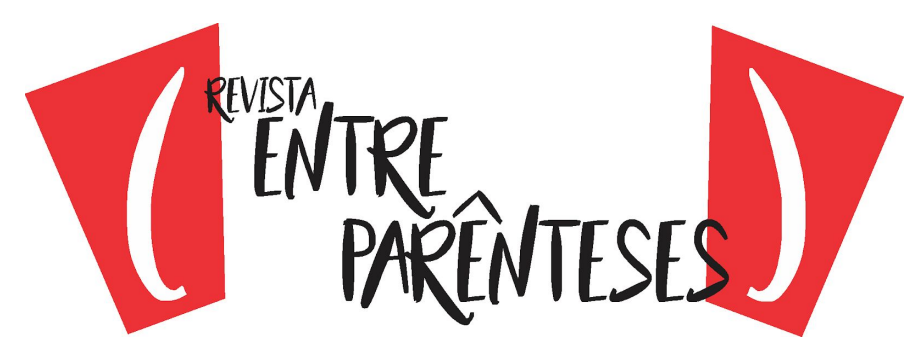

- E quem vai ser oficial, então? Esses que se formam no exército tuga, sem formação política, que um dia tentarão dar um golpe de Estado? É isso que queres? Que depois da independência haja golpes de Estados todos os anos, como nos outros países africanos? Precisamos de ter um exército bem politizado, com quadros saídos da luta de libertação. Como vamos fazer, se os guerrilheiros não querem estudar para serem quadros? (PEPETELA, 1990, p.83).

Assim como o próprio autor, certos personagens, especialmente aqueles que estavam no comando da guerrilha, mostravam preocupações com a formação política do homem angolano, a fim de que pudesse construir uma nação representada por sujeitos que, verdadeiramente, defendessem os princípios democráticos, garantindo uma sociedade mais humanizada. Observe-se que a preocupação do comandante ao indagar "É isso que queres? Que depois da independência haja golpes de estado todos os anos, como nos outros países africanos?" parece, em seguida, ser superada com uma afirmação "Precisamos de ter um exército bem politizado", que analisada mais a fundo implica uma busca de politização não apenas nos limites dos soldados que futuramente iriam proteger o país, mas, sobretudo, a todos os angolanos, principalmente aqueles que iriam ocupar cargos na administração pública. O escritor atribui à literatura a função de fazer e refazer a história de seu país e de seu povo, além de expressar o desejo de liberdade política e autonomia cultural. A narrativa expressa elementos, visões, desejos, imagens que, paulatinamente, caminham para que o romance adquira feição de uma literatura que busca a identidade nacional, assim como percebe Stuart Hall (2003) ao afirmar que

há a narrativa da nação, tal como é contada e recontada nas histórias e nas literaturas nacionais, na mídia e na cultura popular. Essas fornecem uma série de estórias, imagens, panoramas, cenários, eventos históricos, símbolos e rituais nacionais que simbolizam ou representam as experiências partilhadas, as perdas, os triunfos e os desastres que dão sentido à nação. (HALL, 2003, p. 52). 


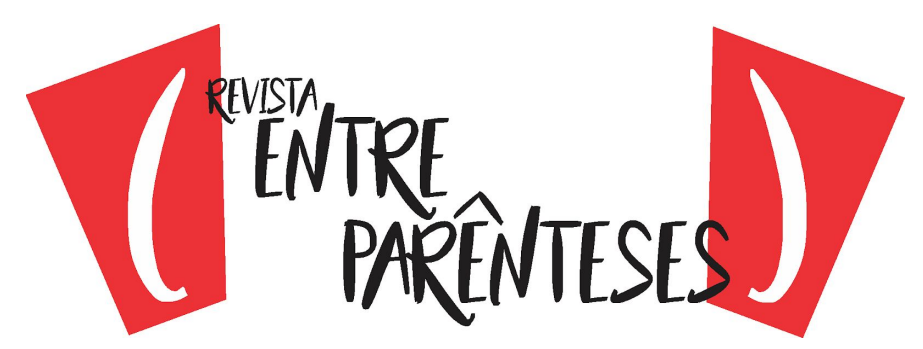

Já Mata (2010) reconhece que a estreita relação existente entre o campo histórico e o literário parte do princípio de que o historiador seleciona os fatos para, então, imprimir performatividade sobre essa seleção e estratégias dispensadas ao discurso histórico. A autora reconhece ainda que

a selectividade é uma condição da pesquisa histórica moderna - o historiador é, pois, natural e necessariamente selectivo e, mais do que "narrador" apenas, é também "demiurgo", criador de um passado segundo os sintomas (interesses, crenças e valores) do presente. $E$, neste contexto, a História também se pode pensar como estratégia de leitura e interpretação do conjunto dos documentos e evidências sobre o passado. (MATA, 2010, p. 134).

Se a história é uma estratégia de leitura do passado, a literatura é também leitura das dimensões da experiência social e histórica, vivenciadas por sujeitos imaginários que conseguem dizer muito da realidade. E numa condição muito próxima do historiador moderno que "seleciona do passado os acontecimentos que (Ihe) interessam às questões que o presente (Ihe) coloca, delimita o período, levanta problemas aos materiais de que dispõe" (MATA, 2010, p. 130), o literato também exerce a função agenciadora na captação de imagens sensíveis do mundo. $\mathrm{E}$, ainda, segundo a mesma autora,

o cruzamento das duas modalidades discursivas dá-se pelo facto de a literatura intentar a captação, pela imaginação, do factual através do discurso narrativo que pretende um sequenciamento histórico, organizando o caótico e o disperso, para o devolver à transparência da interpretação da realidade. (MATA, 2010, p.142).

A partir dessas concepções, percebem-se evidências históricas na narrativa de Pepetela. A voz do personagem Mundo Novo, que por diversas vezes assume a posição de narrador, reflete uma situação política presente durante os longos anos de luta de libertação. Na fala do personagem: 


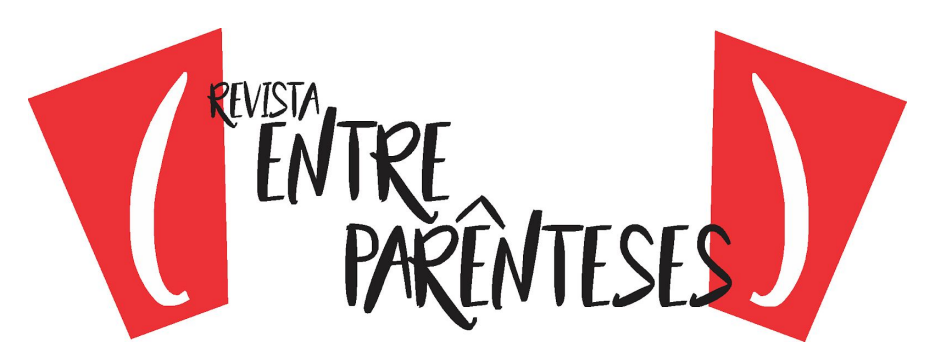

essa atitude faz-me pensar que a relação de forças no Comando vai mudar. Como diz o Chefe de Operações, o desprezo do Comandante pela opinião dos outros membros do Comando tem levado a erros graves, situação agravada pelo facto de o Comissário aprovar sempre Sem Medo.

$[\ldots]$

a Revolução é feita pelas massas populares, única entidade com capacidade para dirigir, não por indivíduos como Sem Medo.

O futuro ver-me-á, pois, apoiar os elementos proletários contra este intelectual que, à força de arriscar a vida por razões subjectivas, subiu a Comandante. A guerra está declarada. (PEPETELA, 1990, p.117-118).

Os diversos conflitos existentes entre os próprios membros da guerrilha que muitas vezes levam à fragmentação do próprio movimento, a necessidade de se posicionar contra os dirigentes, o reconhecimento da importância de uma revolução a ser feita pelas massas populares, a valorização dos elementos proletários expressos na fala do personagem demonstram que a literatura dialoga com a realidade a que se refere de múltiplas maneiras, confirmando a correlação que há entre ficção e historicidade. Mundo Novo é a favor de uma descentralização de poder que por ora concentra-se nas mãos do Comandante Sem Medo, representante intelectual e, dessa forma, Mundo Novo percebe como a história política angolana nos anos precedentes à independência também era marcada por essas questões. A respeito das discussões sobre as dimensões de construção e poder, Joseph Ki-Zerbo (2011) reconhece que,

quanto mais o poder é partilhado, mais ele aumenta. O poder era comparado a um ovo: quando é apertado com muita força, parte-se nas mãos; mas quando não é agarrado com firmeza, pode deslizar da mão e partir-se também. Então, é necessário exercer o poder, nem com demasiada severidade, nem com demasiada negligência. (KI-ZERBO, 2011, p. 64).

Uma questão em pauta sobre a constituição política de muitos países africanos foi a forma pela qual as relações de poder político foram articuladas no 


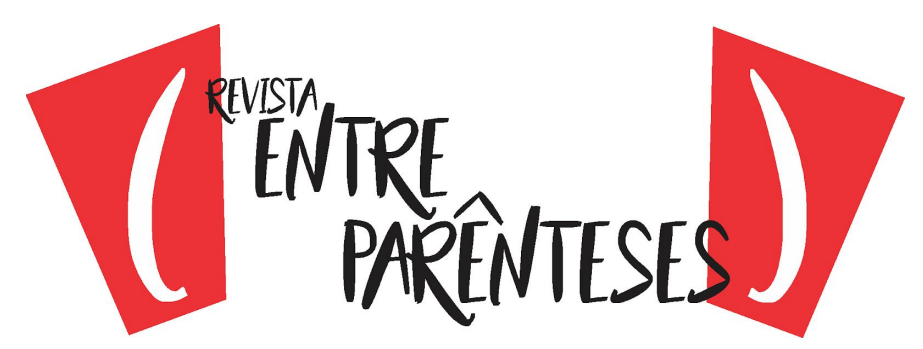

período chamado pós independência. Herdeiros da política colonial, muitos dirigentes africanos implantaram um regime que ainda refletia ações de um passado não muito distante, e, por conseguinte, dificultava em entender a necessidade de legitimar a democracia. É preciso, portanto, desgarrar-se do passado colonial e substituí-lo por novas formas de governos democráticos; em outras palavras, é necessário pensar que "houve tiranos na África, e continua a haver. Mas queremos ficar com as pedras preciosas, e não com os resíduos maus do nosso patrimônio sociocultural” (KI-ZERBO, 2011, p. 64).

\section{BOAVENTURA CARDOSO: TESSITURAS EM NOITES DE VIGÍLIA:}

Segundo Mata (2010, p. 157), “a narrativa em que é vazada a escrita da História não é uma forma neutra de representação de eventos e processos históricos". Essa ideia também faz-se presente logo nas primeiras páginas da narrativa Noites de Vigília, momento em que o narrador ambienta o personagem Quinito com propósito de abrir espaços para que partes da história angolana sejam recontadas e reconfiguradas. De certa forma, apresentar as condições de vida desse personagem e sua rotina diária significa realizar um recorte nada neutro de representação da realidade:

Quinito olhava vagarosamente para as mercadorias expostas, latas de leite em pó, de conservas, de refrigerantes e cervejas, garrafas de vinhos, de uísque, detergente de várias marcas, comparava os preços e conclui rapidamente que o dinheiro que tinha era um nada que não dava para nonadinha. Olhar dele preguiçando e demoroso se remansando na vida... Ah!!, o estar assim acontecendo... no saco das compras trazia um ter, o suficiente para enganar a fome durante dois ou três dias, depois só Deus é quem sabia como que ele ia se ter. (CARDOSO, 2012, p. 9).

Não está em jogo apenas a imaginação do autor e suas preferências estéticas da arte de narrar e apresentar o personagem, sua ambientação e seus 


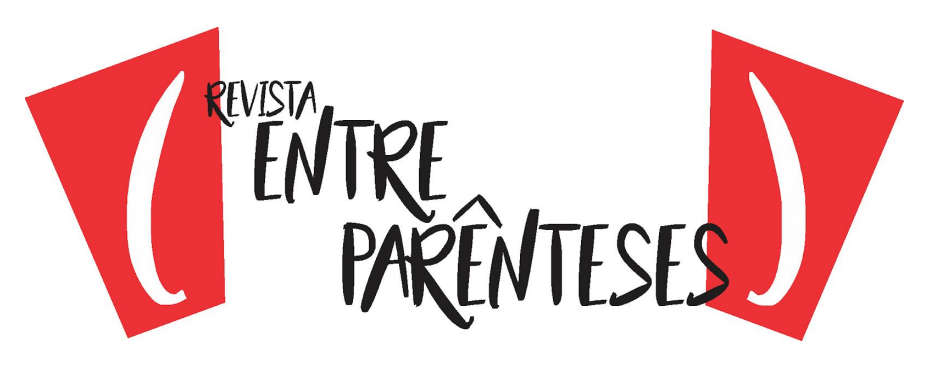

fazeres diários, mas também o desejo de potencializar elementos que ajudam a compreender melhor a realidade, porque como bem lembra Mata (2010, p. 53), "o papel da literatura vai além de sua significação estética e simbólica - tendo, portanto, uma significação extratextual". A partir dessa visão, o leitor consegue realizar uma leitura social da obra, estabelecendo relações entre o universo fictício e o real, aos poucos, a narrativa adquire feições de um gênero apropriado e capaz de reinterpretar cenas de um país marcado por fortes paisagens sociais e tendo o passado e o presente como fontes de leituras e criações de sentido.

Este trabalho está fundamentado em uma visão histórica/literária na qual literatura e história entrecruzam-se num plano de construção/reconstrução, significações/ressignificações dos seres imaginários e históricos relacionados à sociedade angolana, ao tempo em que são importantes também os estudos no campo do processo de colonização e anticolonização do continente africano, mais especificamente de Angola, que giram em torno de aspectos históricos e culturais referentes à história desse país, sem prescindir daqueles outros que explícita e implicitamente tomem parte nessa leitura dialógica, envolvendo os autores Pepetela e Boaventura Cardoso e suas produções literárias no contexto angolano.

Ao publicar uma obra, o autor abre espaço para diversas releituras que se podem realizar sobre ela. O leitor apropria-se do texto e a partir de suportes históricos começa a percorrer caminhos que enveredam pela imaginação e pela força expressiva das palavras, atendendo aos princípios e aos limites da própria interpretação literária. Nesse contexto, pode-se inserir Mayombe, de Pepetela, e Noites de Vigília, de Boaventura Cardoso. Essas obras não apresentam uma história acabada, pelo contrário, as narrativas são relidas e reinterpretadas segundo questionamentos levantados pelo leitor no momento da apropriação textual e da interpretação do que é narrado. Dessa forma, as narrativas apresentam construções discursivas que ajudam a criar imagens representativas do homem angolano e de 


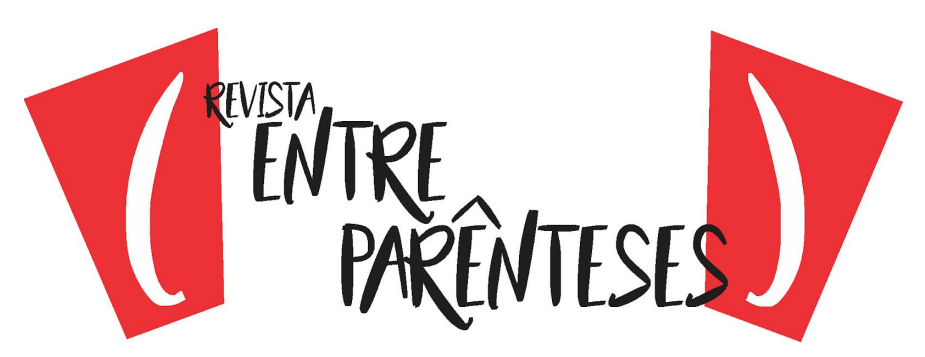

sua realidade. Imagens essas que, reexaminadas, problematizam as diversas situações vivenciadas na sociedade angolana, tanto do passado quanto do presente.

A obra Mayombe pode ser tomada como representação das lutas quanto ao processo de libertação de Angola. A riqueza nas descrições, as relações entre realidade e ficção, a força expressiva dos personagens e os constantes processos mutáveis relativos ao aparato cultural, aos meandros espaciais e ao repertório discursivo do próprio autor dão à obra um alcance maior, fornecendo elementos que proporcionam discussões acerca da história política e cultural desse país. Sem definições propositais de personagem principal, Pepetela constrói um enredo que possibilita a protagonização de vários personagens, transformando, assim, a obra num importante manancial de análises.

O texto ficcional assume uma instância valorativa no campo do conhecimento e o discurso imaginário perene a ele expressa vivências, experiências de lugares e de povos, adquirindo feição histórica. Dessa forma, o discurso ficcional só tem sentido enquanto elo entre os indivíduos e a realidade em que vivem. Daí a importância do imaginário coletivo na construção e na reconstrução da história de um povo. Por isso, para Sandra Jatahy Pesavento (1998)

o discurso ficcional é "quase história", na medida em que os acontecimentos relatados são fatos passados para a voz narrativa, como se tivesse realmente acontecido. Sem dúvida, a narrativa literária não precisa "comprovar" nada ou se submeter à testagem, mas guarda preocupações com uma certa refiguração temporal, partilhada com a história, dando voz ao passado, História e Literatura proporcionam a erupção do ontem no hoje. Esta representação daquilo que "já foi" é que permite a leitura do passado pelo presente como um "ter sido", ao mesmo tempo figurando como um passado e sendo dele distinto. (PESAVENTO, 1998, p. 20).

Como uma possibilidade de recontar muitos fatos dos conflitos do processo de independência de Angola e, principalmente, da guerra civil angolana, instaurada pós-independência, Boaventura Cardoso publicou Noites de Vigília, 


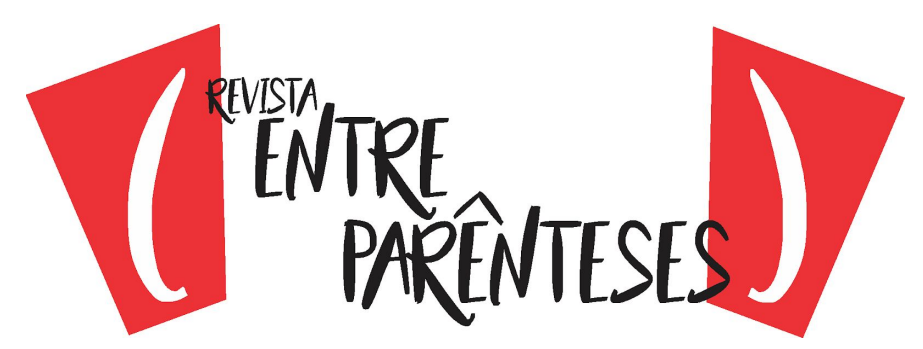

permitindo ao leitor ampliar suas impressões tanto no campo histórico quanto literário daquele período, que, por sinal, é muito bem recortado ao longo do romance. A narrativa abre espaços para que fatos históricos sejam reposicionados e repensados por meio de representações que são acionadas à luz de uma leitura mais crítica e audaciosa. Assim, os personagens Quinito e Saiundo desfilam com tantos outros em um palco repleto de ações cotidianamente vivenciadas pela sociedade angolana durante o período pós-independência política de seu país e, ao mesmo tempo, revivem o passado e partes de acontecimentos que marcaram a própria independência. O cenário imaginativo ganha importância expressiva, atribuindo-Ihe um valor documental que pode ser tomado pela própria história como instrumento de valor investigativo. Assim, literatura e história cruzam-se nas cenas descritivas em Noites de Vigília. Ao discutir sobre aspectos da oralidade presentes em obras de Boaventura Cardoso, Oliveira (2005) afirma que

\begin{abstract}
Boaventura Cardoso imprime determinadas marcas no discurso literário e the confere uma feição testemunhal. O contexto histórico-social, destoante e desconcertante no plano real, torna-se objeto de estudo no plano ficcional e precisa ser redimensionado via representação no texto, espaço significante e de jogos de sentidos para o funcionamento da discursividade de vozes não autorizadas e marginalizadas na sociedade. (OLIVEIRA, 2005, p. 185-186).
\end{abstract}

A cada página que se lê, a cada cenário criado e imaginado, cenas da vida social angolana vêm à tona como se a recriação desse espaço pudesse ajudar o leitor a compreender melhor a paisagem social de um país assolado pelos conflitos civis instaurados pós-independência. O narrador descreve o mercado Roque Santeiro, os sujeitos imaginários que o percorrem e formam aquele espaço e, assim, produz um texto que reflete e, ao mesmo tempo, ajuda a entender a formação social angolana:

[...] para além de algumas pessoas que teriam vindo expressamente ao Roque para saborear um funje de carne ou de peixe. Se dizia que ali no mercado era pitar bué e barato. Ele não duvidava, mas, apesar 


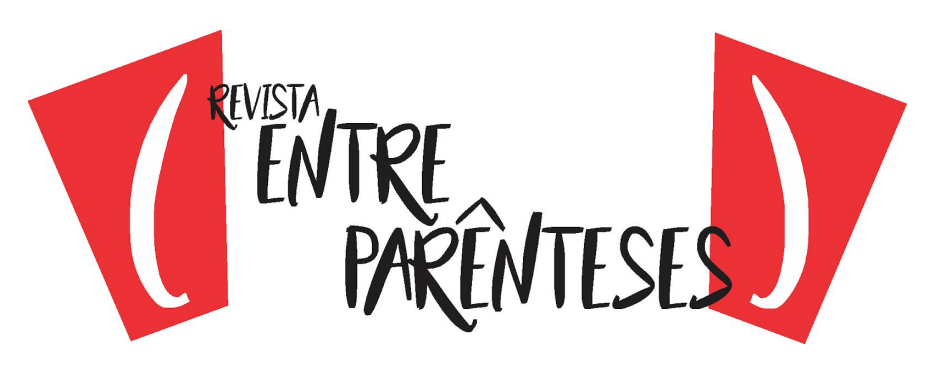

da fome, nunca quisera comer naquesse lugar sempre que viesse ao mercado pois havia muito lixo por perto, as moscas cirandejando, as mulheres que batiam o funje com o suor a lhes escorrer pelo rosto. Reparou que três senhoras, junto a uma barraca, conversavam sobre algumas poucas alegrias das suas vidas, em volta de um panelão, sobre trempe. De vez em quando uma delas destapava o panelão, mexia o seu conteúdo com um pau, provava-o, Ihe tinha no paladar, deitava um pouco de sal e voltava a tapá-lo. Uma das senhoras, com o seio à mostra, amamentava uma criança que aparentava ter, na idade, pouco menos de três luas. (CARDOSO, 2012, p. 10).

Na condição de personagem-narrador, Quinito experimenta um momento de reflexão sobre seu envolvimento na guerra e relembra:

a minha perna... a minha perna... Ihe sinto ainda bem aqui, firme, eu a correr com os meus companheiros de combate, a saltar para cima dos camiões, a atravessar riachos, a fugir do fogo do Inimigo, nos ares a fragor dos combates, a minha perna... (CARDOSO, 2012, p. 11)

A interrupção do pensamento marcado pelas reticências demonstra uma característica muito forte no personagem que é o mergulho no passado, na história angolana. Algo deve ser dito, muito mais forte e simbólico do que a perda da própria perna; e a suspensão do pensamento provoca criações de diversos significados em leitores que criam e recriam cenas da paisagem social da guerra civil angolana instaurada logo após a independência política. A cada estado de imersão na história do país, que por sinal ocorre em diversos momentos da narrativa, o personagem abre espaço não apenas para alimentar a própria criação da arte literária, como também constitui-se em uma forma de pousar no passado e fazê-lo artefato da história. Os mutilados da guerra relembram os árduos anos de conflitos, e no caso específico de Quinito, mesmo sem uma das pernas, ele demonstra, ao longo da narrativa, que essa condição não o impedia de lutar por seu país; em suas palavras: "Aliás, apesar de ter perdido a perna, eu nunca aceitei passar à reserva" (CARDOSO, 2012, p.17-18). 


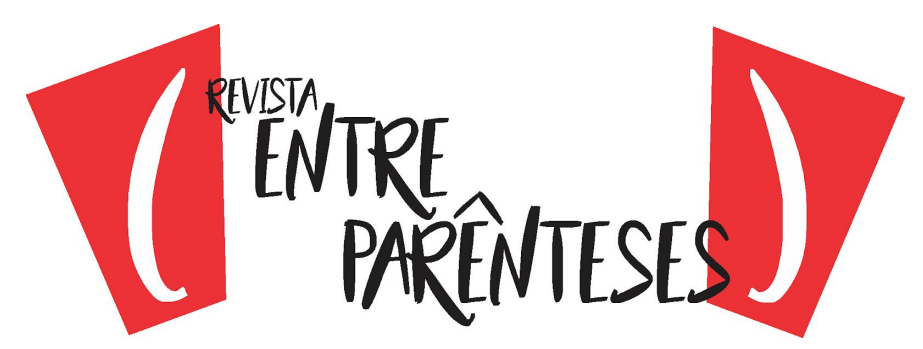

Se Mayombe apresenta recortes dos árduos conflitos da guerra na luta pela libertação do país, Noites de vigília exibe cenários também conflituosos de período do pós- independência e, assim, partes da história angolana são encenadas em textos literários, adquirindo caráter denunciativo e, às vezes, revolucionário. Observe-se como a sociedade angolana pós-independência é vista por Quinito:

Se não formos nós mesmos a lutar pelos nossos interesses, quem há-de lutar por nós nesta sociedade onde o individualismo e a insensibilidade para os problemas sociais parece dominar em todos os sentidos? Os ricos são cada vez mais ricos e os pobres cada vez mais miseráveis. Esta será durante muito tempo a sociedade que teremos se ninguém pensar em resolver os problemas daqueles que lutaram pela defesa da integridade territorial deste país. (CARDOSO, 2012, p.198-199).

O questionamento realizado pelo personagem a respeito do individualismo e da insensibilidade deixa claro a crise social instalada em fragmentos da sociedade angolana. Além disso, verifica-se também que o personagem demonstra consciência sobre a diferença social existente e da necessidade de se fazer algo para amenizar essa problemática. A respeito da situação de Angola pós-independência, Macêdo (2012, p. 106) afirma que,

com a ampliação da guerra civil, a vida nas aldeias e cidades angolanas tornou-se penosa, tendo havido uma notória desarticulação da produção e um decorrente desabastecimento, o transporte terrestre ficou cada vez mais precário e limitado, em razão, também, das minas que se foram espalhando por todo o território nacional. Nesse quadro bastante difícil, os sacrifícios se acumularam e diversos intelectuais foram chamados a participar efetivamente da vida nacional, tanto no exercício de cargos públicos, como através de suas obras literárias.

Como se pode aferir, a trajetória política angolana desde a independência seguiu marcada por lutas e conflitos internos, impossibilitando a integridade territorial e dificultando a concretização de uma sociedade equilibrada economicamente. E, 


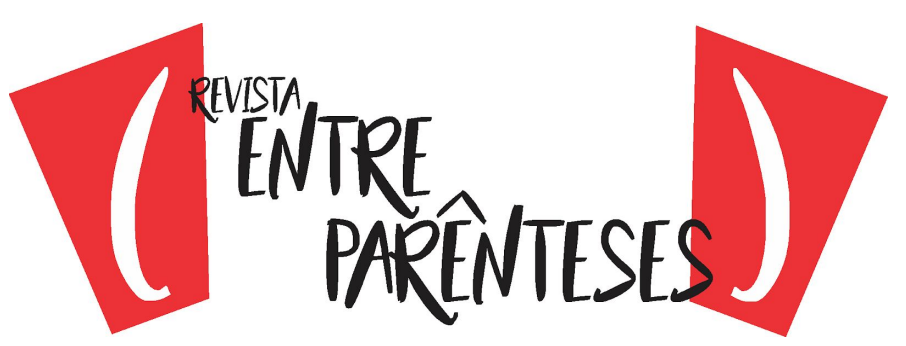

por meio de Quinito e Saiundo, Boaventura Cardoso não mede esforços em apresentar esse novo cenário, transformando seu texto, como tantos outros se empenharam, num ato denunciativo e convocatório. E sobre essa proposta, Macêdo, (2012) reconhece ainda que

há um número expressivo de textos os quais, sob o sinete da memória, ao mesmo tempo em que promovem uma recuperação do passado, projetam um futuro, na medida em que as vivências apresentadas nas narrativas apontam para a construção de uma identidade angolana estilhaçada pela guerra civil e pelo fim das certezas, mas ainda pulsante e capaz de apresentar novos rumos, constituindo-se, sob esse aspecto, em uma espécie de cartografia do devir construída a partir da imaginação e da busca de identidade. (MACEDO, 2012, p. 107-108).

As principais vozes que ecoam na narrativa são as de Quinito e de Saiundo, os principais representantes dos mutilados da guerra. Se as vozes desses sujeitos começam a emergir, significa que partes da história de Angola ganham outras enunciações e, por consequente, outros sentidos também são possíveis de serem construídos. Ao se reencontrarem, os personagens principais revivem momentos do passado e expressam desejos de criar uma organização dos mutilados da guerra com o propósito de reivindicar direitos ao governo. É o que se pode perceber no diálogo abaixo:

- Estou plenamente de acordo contigo. Temos de formar uma associação que vele pelos nossos interesses. Mas o problema agora é saber como começar, nós que nem sequer temos o mínimo para sobreviver. Para formamos uma associação a nível nacional e que seja credível, precisamos de dinheiro para a sua instalação. O mais difícil é começar...

- Vamos amadurecer a ideia. Precisamos, para já, de sensibilizarmos todos os mutilados. (CARDOSO, 2012, p. 19). 


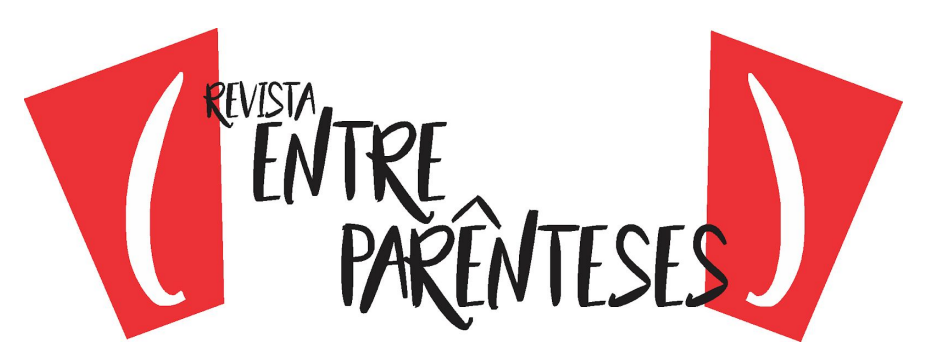

Quando os personagens propõem a criação de uma associação e acreditam que é necessário sensibilizar todos os mutilados, fica também claro que, em outras palavras, a criação de organizações fortalece as relações sociais de um país e a sensibilização do povo implica também poder e conscientização. Esses elementos são importantes para uma nação recentemente criada e que desejava vislumbrar melhores dias para seu povo.

De fato, essas ideias, esses elementos são fundamentais para a organização política e social pela qual Angola passava pós-independência. Então, tudo leva a crer que a narrativa de Boaventura Cardoso enquadra-se também em uma proposta que "permite a passagem do estético ao ético" (MATA, 2010, p. 35). Nesse sentido, a literatura angolana abre espaço para não apenas pensar o contexto social e político de uma época, mas, sobretudo, para pensar o mundo por meio de palavras esteticamente apropriadas, capazes de assumir discursos de indivíduos e sujeitos com função modificadora da sociedade. O autor assume uma consciência estética que the permite evidenciar artisticamente realidades, vivências e testemunhos, sem causar prejuízos na história oficial.

Na perspectiva historiográfica contemporânea, a literatura continua a ser um documento ou fonte, mas o que há para ler nela é a representação que a comporta. Ou seja, a leitura da literatura pela história não se faz de maneira literal, e o que nela se resgata é a representação do mundo que comporta a forma narrativa. Sobre o conceito de representação, Pesavento (1998) ressalta:

as representações são historicamente constituídas, ou seja, se colocam a partir de um campo de forças que se enfrentam e onde se definem as representações do real. Formular uma identidade nacional, desenhar um perfil do cidadão, estereotipar o caráter de um povo correspondem às práticas que envolvem relações de poder e que objetivam construir mecanismos de coesão social. (PESAVENTO, 1998, p. 22) 


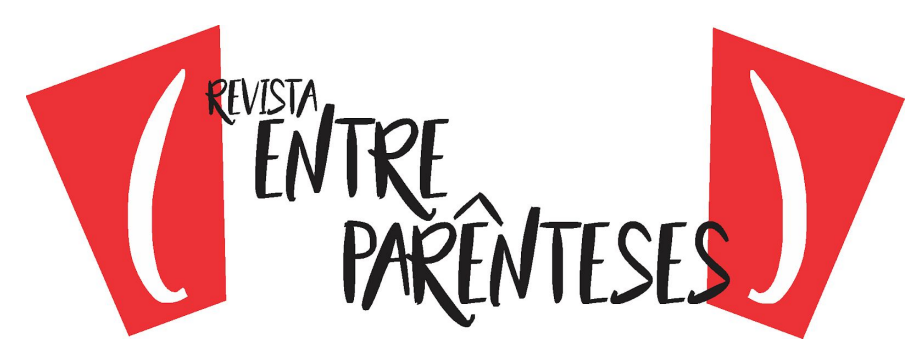

Dessa forma, também se pode afirmar que a história não é passível de uma leitura literal porque é a representação do "real", comportando assim atribuições de sentidos. No entanto, é inegável que a história articula uma fala autorizada sobre os fatos, recria a memória social, interpreta os acontecimentos, dialoga com as fontes com o intuito de provocar debates, enfim reflete aquilo que é mérito de discussão. Nesse sentido, naturalmente não é intenção do texto literário provar que os fatos narrados tenham acontecido concretamente, aproximando-se ou não do discurso histórico; no entanto, é importante lembrar que a narrativa comporta em si uma explicação do real e traduz uma sensibilidade diante do mundo.

Pesavento (1999), ainda discutindo a relação entre história e literatura, percebe que sobre o discurso histórico sobrepõe um narrador, ou seja, uma voz que pode ajudar a redesenhar melhor a cadeia factual dos acontecimentos, fornecendo talvez maiores dados aos fatos narrativos, uma voz que poderá mediar discussão com o leitor. Assim, a autora faz uma importante reflexão:

dizer que a História é uma narrativa verdadeira, de fatos acontecidos, com homens reais, não é, entretanto, afirmar que, como narrativa, ela seja mimese daquilo que um dia teria ocorrido. Assim, há sempre a presença de um narrador que mediatiza uma situação não presenciada por estes. Interpõe-se, assim, um princípio de inteligibilidade e de proposta de conhecimento do ocorrido, que é representado - re-apresentado - a um público ouvinte e leitor. (PESAVENTO,1999, p. 819).

Apesar de a essência do texto literário ser a ficção, historiadores apropriam-se dessa modalidade, realizando pesquisas, sem, contudo, comprometer a veracidade dos fatos e, muito menos, de colocar em posição conflituosa ou perigosa sua pesquisa, tudo vai depender de como ocorre o envolvimento com o fato e como procede o olhar sobre o objeto pesquisado. Sobre essa questão, Pesavento (1999) argumenta ainda que 


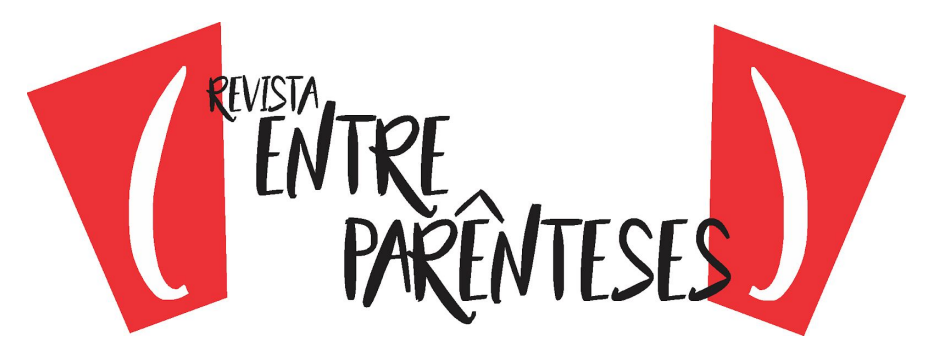

a questão da veracidade e da ficcionalidade do texto histórico está, mais do que nunca, presente na nossa contemporaneidade, fazendo dialogar a literatura e a história num processo que dilui fronteiras e abre as portas da interdisciplinaridade. O texto histórico comporta a ficção, desde que o tomemos na sua acepção de escolha, seleção, recorte, montagem, atividades que se articulam à capacidade da imaginação criadora de construir o passado e representá-la. Há, e sempre houve, um processo de invenção e construção de um conteúdo, o que, contudo, não implica dizer que este processo de criação seja de uma liberdade absoluta. A História, se quisermos definir como ficção, há de se ter em conta que é uma ficção controlada. A tarefa do historiador é controlada pelo arquivo, pelo documento, pelo caco e pelos traços do passado que chegam até o presente. (PESAVENTO, 1999, p. 820).

Se os guerrilheiros de Mayombe lutavam destemidamente pela independência de Angola, os personagens de Noites de Vigília sonhavam com um país que efetivasse a verdadeira independência. Essa ideia se faz presente no pensamento de Quinito:

o outro pedaço de minha vida tu já conheces... A nossa vida começou a dar sinais de mudança, se pressentia que um dia as coisas iam mudar, que a terra ia dar mais pão, que o Sol ia brilhar mais, que as pessoas iam poder falar mais à vontade das coisas da terra, gritar mais livremente, sonhar com asas nos infinitos ares, trabalhar para o bem de uma causa que se sentia ser muito nossa. Se pressentia que a mudança estava para acontecer, que os sonhos que tínhamos sonhado um dia iam se transformar em realidade, que a canção da liberdade ia ser cantada de mãos dadas por todos nós, os filhos desta terra. (CARDOSO, 2012, p. 23).

Assim, a literatura cruza certos momentos históricos da vida social e política de Angola. Ao evidenciar sonhos, desejos, vontades do personagem Quinito, Boaventura Cardoso cria dimensões para que sujeitos reais se vejam presentes nas páginas da narrativa, a fim de que os projetos coletivos possam fortalecer a ideia de criar uma nação verdadeiramente independente. Ideia muito similar é defendida por Ki-Zerbo (2011, p.157) ao afirmar que "a África pode desempenhar um grande papel. 


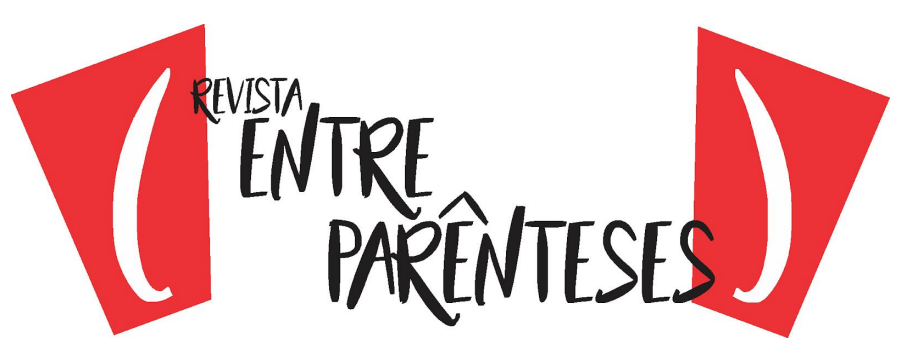

Podemos ir ao fundo da nossa cultura, da nossa civilização, para encontrar um espírito que concilie simultaneamente a liberdade e a igualdade".

Mata (2010, p. 53) afirma que "em determinadas sociedades, como a angolana, a dimensão do literário vai além da ficcionalidade" e isso se torna o principal mote para os narradores contarem e recontarem fragmentos da história de seu país, de seu povo e da sociedade na qual autores, personagens, sujeitos se veem em muitas páginas, em muitos lugares e espaços. Insistindo ainda no fato de que "a ficção é contada a partir da história" (MATA, 2010, p. 53). Observe-se como o narrador descreve a cena abaixo, aproximando aspectos da realidade ao texto ficcional:

Luanda estava a ferro e fogo, com muita violência em todos os recantos da cidade, assaltos, pilhagens e incêndios sobretudo em estabelecimentos comerciais, os bombeiros, sempre em missões de socorro, às vezes para intervir tinham de vencer muitas barricadas, as sirenes das ambulâncias ressoando estridentemente nos ares, gente a correr em direção aos bancos de urgência. Tinha também gente que apesar dos tiros que açoitavam os bairros mais populosos, aproveitavam para pilhar e saquear nas casas comerciais situadas mesmo em zonas urbanizadas, e cujos proprietários brancos tinham abandonado tudo ou confiado seus estabelecimentos a empregados negros convencidos de que isso seria uma garantia para a sua segurança. (CARDOSO, 2012, p. 43-44).

Mesmo no plano ficcional, o narrador, que também é uma criação do autor no plano imaginário, institui ao texto possibilidades de leituras a fatores históricos, a fim de que a cena descrita aproxime-se ao máximo da realidade. $\mathrm{A}$ descrição é marcada, portanto, por violentos acontecimentos, apresentando ao leitor os preços caros pagos pela população angolana por uma independência que se arrastou anos para sua efetivação por causa dos descaminhos dos conflitos existentes no país.

\section{Considerações finais}




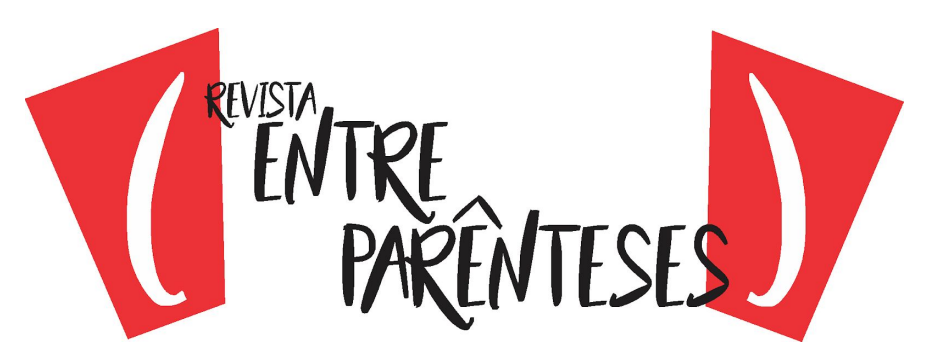

Em termos temporais, Mayombe e Noites de Vigília distanciam-se devido aos períodos históricos dos enredos - mais ainda que da escrita - distanciam-se a ponto de confrontarem-se. Além de constituírem narrativas de nação de diferentes nações desejadas, projetadas e vividas em diversidades. Mas suas histórias, mesmo com focos distintos, acabam se encontrando em um dado lugar, marcando, assim, a complementaridade, de tempos diferentes, por causa da existência de eixos em comum, histórias entrecortadas, séries de percursos e reflexões da vida política e cultural de Angola. Esse ponto de partida e também de chegada permite o cruzamento das linhas do tempo, mesmo elas estando distantes. Assim, os autores dessas narrativas conseguem expressar o imaginário histórico-cultural angolano, problematizar conflitos e tensões e, ao mesmo tempo, construir, por meio de uma escrita convocatória, momentos de inquietações, de releituras, sobre fatos da história angolana. Dessa forma, é perceptível que a arte literária não é apenas um elemento que enfatiza ilusões, devaneios, mas, sobretudo, transforma-se em um recurso capaz de refletir as ações do homem e suas vivências na sociedade, assim como consegue, ainda, reconfigurar ideias e anseios de uma determinada época; em outras palavras, transforma-se em um "ato socialmente político" (JAMESON, 1992, p. 32).

Se a narrativa de Pepetela foi capaz de apresentar aspectos relacionados à guerrilha, importantes e decisivos para a independência da Angola, a obra de Boaventura Cardoso, duas décadas depois daquela publicação e 37 anos depois de nação instituída, também contribui para se refletir sobre um cenário assinalado pelas lutas armadas, conflitos internos, disputas de poder e domínio político, em momentos posteriores à independência, momentos em que se pensava na implementação, nas contradições e em divergentes formas de consolidação de projetos nacionais. 


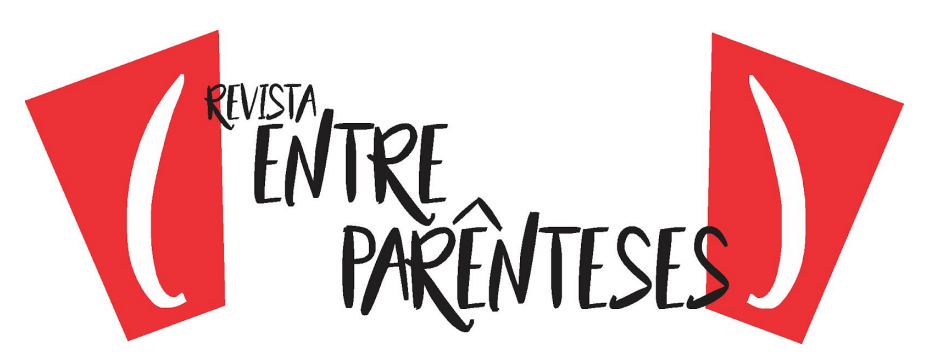

Enfim, as relações entre literatura e história são alvos centrais dos debates que rondam a contemporaneidade, fundamentados desde a sinalização da crise dos paradigmas de análise da realidade, o fim da crença nas verdades absolutas legitimadoras da ordem social até as propostas postuladas pelos estudos interdisciplinares. Na verdade, as teorias gerais que tentaram explicar os fenômenos sociais caem por terra e há, portanto, uma busca de saídas para novas tendências, pautadas na Nova História Cultural. A visão multidisciplinar e plural é uma tentativa de conciliar os diversos pontos de vista, alguns contraditórios, outros convergentes, que promovem discussões acerca do enlace entre literatura e história, conforme pudemos perceber nessas tessituras de Mayombe e Noites de Vigília.

\section{REFERÊNCIAS}

CARDOSO, Boaventura. Noites de Vigília. São Paulo: Terceira Margem, 2012.

CHARTIER, Roger. Cultura escrita, literatura e história. Trad. Ernani Rosa. Porto Alegre: Artmed, 2001.

CHALHOUB, Sidney; PEREIRA, Leonardo Affonso de M. Apresentação. In: (Org.). A história contada capítulos de história social da literatura no Brasil. Rio de Janeiro: Nova Fronteira, 1998. p. 7-13.

HALL, Stuart. Da diáspora: identidades e mediações culturais. Trad. Adelaine La Guardia Resende et al. Belo Horizonte: Editora da UFMG, 2003.

ISER, Wolfgang. Os atos de fingir ou o que é fictício no texto ficcional. In: Lima, L. C. Teoria da literatura em suas fontes. v. 2. Rio de Janeiro: Civilização Brasileira, 2002.

JACQUES \& PESAVENTO, Sandra Jatahy (Org.). Discurso histórico e narrativa literária. Campinas, SP: Editora UNICAMP, 1998. p. 17-40.

JAMESON, Fredric. O inconsciente político: a narrativa como ato socialmente simbólico. Trad. São Paulo: Editora Ática, 1992.

KI-ZERBO, Joseph. História geral da África. V.8. São Paulo: Cortez/ UNESCO. 2011. 


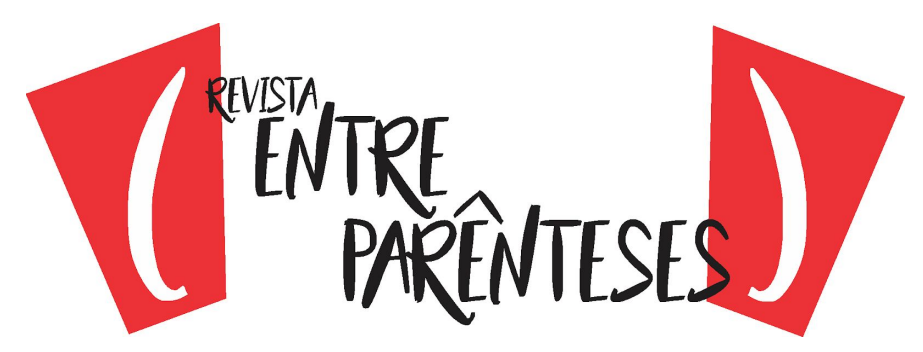

MACEDO, Tânia. Itinerários da memória na escrita da literatura angolana contemporânea. IN: COSTA, Fernanda Gil \& MATA, Inocência. Colonial/Post-Colonial: Writing as Memory in Literature. Lisboa: Colibri, 2012.

MATA, Inocência. Pepetela: A releitura da história entre gestos de reconstrução. In: CHAVES, Rita \& MACÊDO, Tania (Org.). Portanto... Pepetela. São Paulo: Ateliê Editorial, 2009.

Mayamba, 2010.

Ficção e história na literatura angolana: o caso de Pepetela. Luanda:

OJE-ADE, Femi. Cultura africana: do velho e do novo; os anos 90. Disponível em http://www.afroasia.ufba.br/pdf/afroasia_n16_p36.pdf, acessado em 17 de agosto de 2014, às $9 h$.

OLIVEIRA, Jurema José de. A oralidade nos tempos modernos. In: CHAVES, Rita; MACÊDO, Tania \& MATA, Inocência. Boaventura Cardoso a escrita em processo. São Paulo: Alameda, União dos Escritores Angolanos, 2005. p. 185-194.

PEPETELA, Artur Carlos Maurício Pestana dos Santos. Mayombe. 7. ed. Publicações Dom Quixote.1990.

PESAVENTO, Sandra Jatahy. Contribuição da história e da literatura para a construção do cidadão: A abordagem da identidade nacional. In: LEENHARDT,

O Imaginário da cidade: visões literárias do urbano. Porto Alegre: Editora UFRGS, 1999.

ROSÁRIO, Lourenço do. O homem angolano. In: CHAVES, Rita \& MACÊDO, Tania (Org.). Portanto... Pepetela. São Paulo: Ateliê, 2009. p. 225-229.

Recebido em: 23/06/2009

Aceito em: 20/01/2020 